\title{
PENGARUH PERSON-ORGANIZATION FIT TERHADAP KOMITMEN ORGANISASIONAL MELALUI KEPUASAAN KERJA PADA KARYAWAN IBI (INFORMATICS AND BUSINESS INSTITUTE) DARMAJAYA
}

\author{
Stefanus Rumangkit \\ Sri Maryati \\ Informatics and Business Institute Darmajaya \\ Srimaryati.25091990@gmail.com
}

\begin{abstract}
This study aims to examine the influence of person organization fit on organizational commitment with work satisfaction as a mediator variable. The data collected as many as 150 respondents obtained from educative employees Institute of Informatics and Business Darmajaya in the years of 2017. From the data obtained, then performed data analysis using the regression model of mediation through a simple regression analysis and multiple regression method. The results of this study indicate that the person organization fit has a positive and significant effect on organizational commitment. From the results of this study can be reported that the socialization of the organization have a positive and significant impact on the suitability of values. Other findings from this study indicate that conformity values have a positive and significant effect on affective commitment. In addition, the results of this study also indicate that conformity values mediate the effect of organizational socialization on affective commitment.
\end{abstract}

Keywords: P-O Fit, Organizational Comitment, Work Satisfaction

\section{PENDAHULUAN}

Studi mengenai komitmen organisasional seringkali menjadi topik yang menarik bagi para peneliti sumberdaya manusia dan organisasi. Penelitian mengenai komitmen organisasional merupakan tema yang banyak dipilih oleh para peneliti (Luthan, 1995). Hal ini terjadi karena tema komitmen organisasional tersebut dapat digunakan untuk memahami dan memprediksi perilaku kerja seperti: tingkat kemangkiran, tingkat keluarnya karyawan, dan kinerja manajer (Sanusi, 2012). Perhatian para peneliti tersebut tersebar dalam berbagai konsep dan cara pengukuran komitmen organisasional yang berbeda-beda (Allen dan Meyer, 1990; Biswas \& Bhatnagar, 2013).

Salah satu variabel yang digunakan untuk memprediksi komitmen adalah personorganization fit atau sering yang disingkat dengan istilah $P$-O fit. Hanich dan Hulin (1990) menyatakan bahwa $P$-O fit dapat meningkatkan kepuasaan kerja dan komitmen organisasional yang dirasakan oleh karyawan, sehingga dapat menurunkan perilaku turnover intention, perilaku adiktif dan pergeseran kepemimpinan (Jutras \& Mathieu, 2016). 
Pengaruh Person-Organization Fit Terhadap Komitmen Organisasional Melalui Kepuasaan Kerja ...........

Schneider(1987) menawarkan pendekatan kerangka kerja ASA (Attraction-SelectionAttrition) dalam menilai $P-O$ fit, Schneider berpendapat bahwa individu dan organisasi saling tertarik manakala terdapat kesesuaian (compatibility) antara satu dengan yang lain, hal ini sangat berpengaruh terhadap organisasi dalam merekrut karyawan dan juga sikap karyawan untuk memilih pekerjaan tersebut. Beberapa bukti empiris mendukung pernyataan ini (Boxx et al., 1991; Chatman, 1991; O’ Reilly, Chatman \& Caldwell, 1991; Vancouver \& Smitt, 1991).

Beberapa penelitian terdahulu mengindikasikan bahwa $\mathrm{P}-\mathrm{O}$ fit berhubungan dengan reaksi terhadap pekerjaan (Kristof, 1996; Netemeyer et al, 1997). Ketika nilai-nilai individu dan organisasi sama, maka hal ini akan meningkatkan kepuasan kerja dan komitmen organisasional serta akan mengurangi stress kerja karyawan (Mount \& Muchinsky,1978; Silverthone, 2004). Hal yang sama juga ditemukan oleh (Valentine et. Al, 2002; Chadwell dan O' Reilly, 1991). Akan tetapi tidak semua penelitian menunjukkan bahwa $P-O$ fit berpengaruh positif terhadap komitmen organisasional, hal ini dilihat dari penelitian yang dilakukan oleh Meglino, Ravlin, dan Adkins (1992) dan Hsieh, Edb \& Chen (2011)..

Ketidakkonsistenan ini didasarkan peneliti tidak menemukan adanya perbedaan definisi, teori, dan alat ukur yang digunakan, tetapi perbedaan terjadi karena konteks yang berbeda. dimana penelitian Meglino, Ravlin, dan Adkins dilakukan pada perusahaan manufaktur yang terletak di South eastern United State. Sedangkan Box, Oddom, dan Dunn (1991) meneliti hubungan $\mathrm{P}-\mathrm{O}$ fit dengan komitmen organisasional pada perusahaan sektor publik. Untuk itu, penelitian ini menggunakan konteks industri pendidikan, yaitu IIB Darmajaya Lampung

Dalam penelitian kali ini, peneliti mempertimbangkan kepuasaan kerja sebagai variabel pemediasi seperti yang telah disarankan oleh beberapa peneliti. Verquer, Beehr, Wagner (2002) menyatakan pengaruh $P-O$ fit terhadap sikap kerja termasuk komitmen organisasional harus dilakukan analisis lebih jauh karena kemungkinan terdapat variabel yang dapat mempengaruhi hubungan $\mathrm{P}-\mathrm{O}$ fit dan komitmen organisasional. Selain itu, perlu dilakukan penelitian lebih lanjut untuk menguji $\mathrm{P}-\mathrm{O}$ fit dengan komitmen organisasional dalam konteks lain, dengan mempertimbangkan industri dan demografi berbeda. Oleh karena itu, penelitian ini akan dilakukan pada industri pendidikan dan memasukkan variabel pemediasi yaitu kepuasaan kerja. Kepuasaan kerja merupakan anteseden dari komitmen organisasional (Jernigan et.al, 2002; Mowday et.al, 1982) dan berbagai anteseden dari komitmen organisasional dapat dimediasi oleh kepuasaan kerja (Iverson dan Roy, 1994; Lok \& Crawford, 2001; Michaels, 1994). Dalam kaitannya dengan komitmen organisasional, kepuasaan kerja dapat meningkatkan komitmen organisasional individu (Rue, 2005; O’Reilly dan Caldwell, 1980). Menurut Verquer, Beehr, Wagner (2002) diperlukan adanya treatmen mediasi, komitmen organisasi dan kepuasaan kerja merupakan kekuatan psikologis yang dapat meningkatkan kinerja (Gregory, Albritton \& Osmonbekov, 2010).

\section{REVIEW LITERATUR DAN HIPOTESIS}

\section{Person-Organization Fit}

Person organization Fit (P-O fit) secara luas didefinisikan sebagai kesesuaian antara nilai-nilai organisasi dengan nilai-nilai individu (Kristof,1996). Pada penelitian tentang seleksi karyawan, P-O fit dapat diartikan sebagai kecocokan atau kesesuaian antara calon karyawan dengan atribut-atribut organisasi (Judge \& Ferris, 1992). P-O fit didasarkan pada asumsi keinginan individu untuk memelihara kesesuaian 
mereka dengan nilai-nilai organisasi (Schneider, Goldstein, \& Smith, 1995).

Temuan terdahulu menunjukkan bahwa individu dan organisasi saling tertarik manakala terdapat kesesuaian (compatibility) antara satu dengan yang lain, hal ini sangat berpengaruh terhadap organisasi dalam merekrut karyawan dan juga sikap karyawan untuk memilih pekerjaan tersebut. Beberapa bukti empiris mendukung pernyataan ini (Boxx et al., 1991; Chatman, 1991; O' Reilly, Chatman \& Caldwell, 1991; Vancouver \& Smitt, 1991). Berdasarkan dari pengertian Person-Organization Fit (P-O Fit) tersebut, maka para peneliti menggunakan kesesuaian nilai-nilai sebagai operasional dari $P$-O Fit karena (1) nilainilai adalah fundamental dan mempertahankan karakteristik dari individual dan organisasi (Chatman, 1991) dan (2) nilai-nilai meramalkan sejumlah outcomes individu yang meliputi kepuasan dan perilaku yang bertujuan (Meglino et al., 1992).

Menurut Kristof (1996), PersonOrganization Fit (P-O Fit) dapat terbagi dalam empat konsep yaitu :

a) Kesesuaian nilai (value congruence), adalah kesesuaian antara nilai instrinsik individu dengan organisasi (Boxx, Odom, \& Dunn, 1991; Chatman, 1989,1991; Judge \& Bretz, 1992; Posner, 1992 pada Sekiguchi, 2004).

b) Kesesuaian tujuan (goal congruence), adalah kesesuaian antara tujuan individu dengan organisasi dalam hal ini adalah pemimpin dan rekan sekerja (Sekiguchi, 2004; Vancouver , Vancouver-Schmitt, 1991).

c) Pemenuhan kebutuhan karyawan (employee need fulfillment) adalah kesesuaian antara kebutuhan-kebutuhan karyawan dan kekuatan yang terdapat dalam lingkungan kerja dengan sistem dan struktur organisasi (Cable \& Judge, 1994; Turban \& Keon, 1994) d) Kesesuaian karakteristik kultur-kepribadian (culture personalit congruence) adalah kesesuaian antara kepribadian (non nilai) dari setiap individu dan iklim atau kultur organisasi (Bowen, Ledrof \&Nathan, 1991).

\section{Komitmen Organisasional}

Komitmen organisasional merupakan suatu dimensi perilaku yang penting dan dapat digunakan untuk mengevaluasi seberapa besar dedikasi karyawan pada organisasi. Pada dasarnya, faktor pribadi maupun faktor organisasi sama-sama memiliki pengaruh terhadap komitmen. Komitmen yang terbentuk tersebut akan berpengaruh secara negatif dengan variabel turnover karyawan dan ketidakhadiran serta berpengaruh secara positif dengan performa kerja (Meyer et al, 2002).

Mowday et al (1982) berpendapat jika seorang karyawan memiliki komitmen pada organisasi berarti karyawan tersebut memiliki identifikasi diri yang kuat pada organisasi, menerima sistem nilainya, bersedia untuk bertahan menjadi anggota organisasi dan mau bekerja dengan sungguh-Sungguh demi organisasi. Selain menerima sistem nilainya, karyawan dengan komitmen tinggi juga akan memberikan segala usaha, kemampuan dan loyalitasnya untuk mewujudkan nilai dan tujuan organisasi tersebut.

Allen dan meyer (1990) mendefinisikan komitmen organisasional sebagai keadaan psikologi yang mengikat individu pada organisasi (dan menurunkan perpindahan karyawan). Dalam penelitian mereka berikutnya, Meyer dan Allen (1991) mendefinisikan komitmen organisasional sebagai derajat seberapa jauh pekerja mengidentifikasi dirinya dengan organisasi dan keterlibatannya dalam organisasi. Menurut Allen dan Meyer terdapat tiga komponen komitmen organisasional yaitu komitmen afektif (AOC), komitmen kontinuan (COC), dan komitmen 
Pengaruh Person-Organization Fit Terhadap Komitmen Organisasional Melalui Kepuasaan Kerja ...........

normatif (NOC). Pengertian secara singkat dari komponen-komponen komitmen organisasional adalah AOC merupakan keinginan karyawan untuk tetap bertahan dalam organisasi, sedangkan COC merupakan kebutuhan karyawan untuk tetap bertahan dalam organisasi, dan NOC merupakan rasa tanggung jawab karyawan untuk bertahan di dalam organisasi. Penelitian Allen dan Meyer (1990) menunjukkan bahwa ketiga komponen komitmen organisasional ini keterandalannya dapat dipercaya. Ketiga komponen ini dibangun dari berbagai pengalaman kerja yang berbeda. Jadi komitmen organisasional dari setiap karyawan juga berbeda-beda sesuai dengan pengalaman kerjanya, ada yang memiliki AOC dan COC tinggi tapi NOC rendah, ada yang memiliki AOC dan NOC tinggi tapi COC rendah, dan lain sebagainya.

Karena pentingnya ketiga komponen tersebut maka penting bagi kita untuk mengetahui faktor-faktor yang mempengaruhinya. Menurut Allen dan Meyer (1990) faktor-faktor yang mempengaruhi AOC adalah pengalaman kerja dan kenyamanan individu (kepercayaan organisasi, keserasaian dengan teman kerja, dan kejelasan peran). Karyawan yang merasa nyaman dengan pekerjaannya dan merasa berkompeten dalam pekerjaannya maka akan memiliki AOC yang lebih besar pada organisasi. Penelitian lain membuktikan bahwa AOC berhubungan positif dengan kepuasaan kerja, pengalaman kerja, persepsi terhadap dukungan organisasi, keadilan organisasi dan kondisi pekerjaan yang diharapkan (Meyer et al, 2002).

\section{Kepuasaan Kerja}

Kepuasan kerja adalah cara seseorang pekerja merasakan pekerjaannya, yaitu yang mendukung atau tidak mendukung dari karyawan yang berhubungan dengan kondisi dirinya (Wexley dan Yukl, 1992). Porter (2007) mengatakan bahwa kepuasaan kerja adalah selisih dari sesuatu yang seharusnya ada dengan sesuatu yang sesungguhnya ada (factual). Semakin kecil selisih kondisi yang seharusnya dan kondisiactual, seseorang akan cenderung merasa semakin puas. Menurut Gibson (2000) kepuasaan kerja adalah sikap seseorang terhadap pekerjannya. Sikap tersebut berasal dari persepsi mereka mengenai pekerjaannya dan hal ini tergantung pada tingkat outcomes intrinsik maupun eksterinsik dan bagaimana pekerja memandang outcome tersebut. Kepuasaan kerja akan mencerminkan persaaan mereka terhadap pekerjaannya. Meskipun demikian kepuasaan kerja tidak dapat secara langsung dilihat secara kasat mata tetapi dapat diperhatikan melalui perilaku yang ditunjukkan dan apa yang mereka ungkapkan lewat kata-kata. Pemenuhan kepuasaan kerja karyawan selain dapat mengurangi resiko keluarnya karyawan dari perusahaan juga mampu meningkatkan produktivitas kerja, sehingga selayaknya menjadi perhatian bagi perusahaan agar dapat menjadi suskes.

Smith et al (1995) menyatakan ada tiga aspek utama dimana akan memberikan respon terhadap kepuasan kerja, yaitu: (1) Individu : dipengaruhi oleh usia, jenis kelamin, pengalaman dan sebagainya. (2) Pekerjaan : dipengaruhi oleh otonomi pekerjaan, kreatifitas yang beragam identitas tugas, keberartian tugas (task significancy), rekan sekerja, gaji, dan kesempatan promosi serta pekerjaan tertentu yang bermakna dalam organisasi dan lain-lain. (3) Organisasional: dipengaruhi oleh skala usaha, kompleksitas organisasi, formalisasi, sentralisasi, jumlah anggota kelompok, lamanya beroperasi, usia kelompok kerja, kepemimpinan.

Wexly dan Yukl (1977) menyatakan kepuasaan kerja yang dirasakan seseorang tergantung dengan apakah ia merasakan keadilan (equity) atau tidak atas situasi. Perasaan ini diperoleh dengan cara membandingkan dirinya 
dengan orang lain yang setingkat, sekantor maupun ditempat lain. Menurut teori ini ada tiga elemen keadilan yaitu input, outcomes seorang pembanding, dan adanya situasi equity-inequity. Input yaitu segala sesuatu yang berharga yang diterima oleh karyawan sebagai hasil atau sumbangan terhadap pekerjaannya. Outcomes adalah segala sesuatu yang berharga yang diterima oleh karyawan sebagai hasil dari pekerjaan. Menurut teori ini seseorang menilai adil dengan membandingkan rasio input dan outcomes yang dimiliki orang lain, sedangkan yang menjadi pembanding dapat dipakai orang lain dalam perusahaan yang sama atau perusahaan lain, dapat juga dengan membandingkan diri sendiri di masa lampau. Bila pembanding itu dirasa cukup adil maka ia akan merasa puas, demikian juga sebaliknya.

\section{Pengaruh Person-Organization Fit Terhadap Komitmen Organisasional}

Komitmen organisasional merupakan salah satu bagian dari sikap karyawan yang diinginkan oleh organisasi, hal ini dikarenakan komitmen organisasional membawa dampak yang positif terhadap organisasi, seperti: kinerja yang baik, sikap disiplin kerja yang tinggi, rendahnya tingkat turnover karyawan, dan terciptanya perilaku "extra role" atau tindakan proporsional yang dilakukan individu diluar dari pekerjaan formal yang menguntungkan organisasi (Chatman, 1991).

Salah satu faktor yang dapat diduga mempengaruhi komitmen organisasional adalah person-organization fit. Kristof (1996) menyatakan P-O fit sebagai kesesuaian antara nilai-nilai organisasi dengan nilai-nilai individu. Pada penelitian ini peneliti merujuk pada dimensi $\mathrm{P}-\mathrm{O}$ fit, yaitu value congruence. Chatman ,(1989) menyatakan value congruence sebagai kompatibilitas nilai-nilai antara individu dengan entitas organisasi yang lain, seperti: rekan kerja, supervisor, kelompok kerja, dan organisasi secara keseluruhan. Robbins (2001) yang memiliki pandangan bahwa sikap dan perilaku karyawan dapat dipengaruhi oleh norma dan budaya yang terbentuk dari nilai-nilai yang berada didalam organisasi.

Theory of work adjustment menyatakan bahwa kesuksesan hubungan kerja terjadi dari hasil kesesuaian nilai-nilai dan karakteristik antara individu dengan organisasi, yang nantinya akan mempengaruhi sikap, seperti: komitmen organisasional, kepuasaan kerja karyawan, dan keterlibatan kerja (Bretz dan Judge, 1994). Cognitive dissonance theory juga mendukung hal tersebut, dikatakan bahwa jika nilai-nilai individu dengan organisasi mengalami kesesuaian maka karyawan memiliki keyakinan yang kuat,sehingga individu akan mengarah pada sikap yang positif dan akan mengurangi distonansi kognitif (Elliot dan Devine, 1994).

Dari Uraian diatas dan beberapa temuan empiris dari penelitian terdahulu, maka dengan ini peneliti menduga bahwa $\mathrm{P}-\mathrm{O}$ fit memiliki pengaruh yang positif terhadap komitmen organizational, sehingga peneliti mengajukan hipotesis pertama yaitu:

\section{$\mathrm{H}_{1}$ : Person organization fit berpengaruh pada komitmen organisasional}

\section{Pengaruh Person Organization Fit terhadap Kepuasaan Kerja}

Banyak sumber dari penelitian terdahulu telah memberikan penilaian teoritis dan bukti empiris yang membuktikan bahwa PersonOrganization Fit memiliki pengaruh yang positif terhadap kepuasan kerja (Kristoff, 1996; Netemeyer et al., 1997; Chatman, 1991). Menurut Chatman (1991) dalam penelitiannya pada akuntan publik menyimpulkan adanya pengaruh positif antara Person-Organization 
Pengaruh Person-Organization Fit Terhadap Komitmen Organisasional Melalui Kepuasaan Kerja ...........

Fit (P-O Fit) dengan kepuasan kerja. Beberapa penelitian terdahulu mengindikasikan bahwa P-O fit berhubungan dengan reaksi terhadap pekerjaan (Kristoff, 1996; Netemeyer et al., 1997). Ketika nilai-nilai individu dan organisasi sama, maka hal ini akan meningkatkan kepuasan kerja dan kinerja serta akan mengurangi stress kerja karyawan (Mount \& Muchinsky, 1978 pada O' Reilly et al., 1991). Chadwell dan O' Reilly (1991) menguji kesesuaian (congruency) individu dan organisasi dengan kinerja, mereka menemukan bahwa P-O fit berhubungan positif terhadap kepuasan kerja dan kinerja. Hal yang sama juga dikemukakan oleh (Barrett, 1995; Tziner, 1987 pada Sekiguchi, 2004).

Bowen et al (1991) berargumentasi bahwa memilih orang-orang yang kepribadian sama dengan nilai organisasi akan menciptakan suatu sikap pekerja yang fleksibel. Di dalam tinjauan Kristof (1996) membuktikan secara empiris bahwa P-O Fit adalah prediktor kuat kepuasan kerja dan komitmen organisasi luas (Boxx, Odom \& Dunn,1991; Chatman, 1991; O'Reilly, Chatman\& Caldwell, 1991). Beberapa penelitian di atas menyimpulkan bahwa PersonOrganization Fit (P-O Fit) merupakan determinan yang potensial terhadap kepuasan kerja.

Dari Uraian diatas dan beberapa temuan empiris dari penelitian terdahulu, maka dengan ini peneliti menduga bahwa $\mathrm{P}-\mathrm{O}$ fit memiliki pengaruh yang positif terhadap komitmen organizational, sehingga peneliti mengajukan hipotesis kedua yaitu:

\section{$\mathrm{H}_{2}$ : Person organization fit berpengaruh pada kepuasaan kerja}

\section{Pengaruh Kepuasaan Kerja Terhadap Komitmen Organisasional}

Kepuasaan kerja mengacu pada sikap individu terhadap pekerjaanya. Robbins (2003) menyatakan kepuasaan kerja merupakan keadaan emosional yang menyenangkan yang dihasilkan dari penilaian pekerjaan tersebut. Smith et al (1969) menemukan bahwa pekerjaan itu sendiri, rekan kerja, supervisi, gaji, kondisi kerja, kebijakan perusahaan, prosedur dan kesempatan untuk promosi merupakan aspek-aspek pekerjaan yang dapat mempengaruhi tingkat kepuasaan kerja individu. Teori side-bets menyatakan bahwa komitmen organisasi akan terjadi dikarenakan para anggota organisasi memiliki akumulasi investasi yang cukup tinggi, sehingga bila iya meninggalkan organisasi investasi tersebut akan hilang. Investasi yang dimaksud bisa berupa keterikatan atau koneksi yang sudah terjalin dengan rekan kerja, supervisor,maupun organisasi, prestasi kerja, dan kedudukan yang lebih tinggi atau senioritas (Alutto, Hrebiniak, \& Alonso, 1973; Meyer \& Allen, 1984; Sheldon, 1971).

Gunlu et al (2010) menemukan kepuasaan kerja berpengaruh signifikan pada komitmen organisasional. Kwantes (2009) melakukan penelitian terhadap para insinyur di Amerika dan India, dan menemukan kepuasaan kerja berpengaruh pada komitmen organisasional. Mosadeghrad et al (2008) melakukan penelitian untuk melihat hubungan antara kepuasaan kerja, komitmen organisasional, dan niat untuk keluar karyawan rumah sakit. Hasil penelitian mereka menemukan karyawan di rumah sakit memiliki tingkat kepuasaan kerja yang tinggi sehingga mereka lebih berkomitmen terhadap pekerjaan dan organisasinya.

Dari Uraian diatas dan beberapa temuan empiris dari penelitian terdahulu, maka dengan ini peneliti menduga bahwa $\mathrm{P}-\mathrm{O}$ fit memiliki pengaruh yang positif terhadap komitmen organizational, sehingga peneliti mengajukan hipotesis ke ketiga yaitu:

\section{$\mathrm{H}_{3}$ : Kepuasaan kerja berpengaruh pada komitmen organisasional}


Pengaruh Mediasi Kepuasaan Kerja Pada Pengaruh Person Organization Fit dan Komitmen Organisasional

Valentine et al (2002) menguji P-O fit dengan komitmen organisasi, mereka menemukan bahwa P-O fit berhubungan positif dengan komitmen organisasi. Hal yang sama juga dikemukakan oleh Chadwell dan O' Reilly (1991) menguji kesesuaian (congruency) individu dan organisasi dengan kinerja, mereka menemukan bahwa P-O fit berhubungan positif dan kuat terhadap kepuasan kerja, yang pada akhirnya memperkuat komitmen karyawan terhadap organisasi. Penelitian lain yang dilakukan oleh Silverthone (2003) meneliti tentang pengaruh $\mathrm{P}-\mathrm{O}$ fit dengan komitmen organisasi di negara Taiwan, dan menemukan bahwa P-O fit berpengaruh terhadap komitmen dan kepuasaan kerja karyawan.

Chadwell dan O' Reilly (1991) menguji kesesuaian (congruency) individu dan organisasi dengan kinerja, mereka menemukan bahwa P-O fit berhubungan positif dan kuat terhadap kepuasan kerja dan kinerja. Hal yang sama juga dikemukakan oleh (Barrett, 1995; Tziner, 1987 pada Sekiguchi, 2004). Sedangkan penelitian yang dilakukan oleh Aurthy \& Daugherty (2003) bertolak belakang dengan hasil temuan penelitian yang dilakukan oleh Chadwell dan O' Reilly (1991); dan Bretz dan Judge (1994), dimana Aurthy \& Daugherty (2003) menguji hubungan P-O Fit dengan kepuasan kerja pada karyawan warehouse (gudang) di Inggris dan Spanyol menemukan hasil yang tidak signifikan antara keduanya terutama untuk dimensi kesesuaian (fit) dengan rekan kerja

Dari Uraian diatas dan beberapa temuan empiris dari penelitian terdahulu, maka dengan ini peneliti menduga bahwa $\mathrm{P}-\mathrm{O}$ fit memiliki pengaruh yang positif terhadap komitmen organizational, sehingga peneliti mengajukan hipotesis keempat yaitu:

\section{$\mathrm{H}_{4}$ : Kepuasaan kerja memediasi pengaruh pengaruh person organization fit terhadap komitmen organisasional}

Berikut adalah gambar kerangka pemikiran dalam penelitian ini,

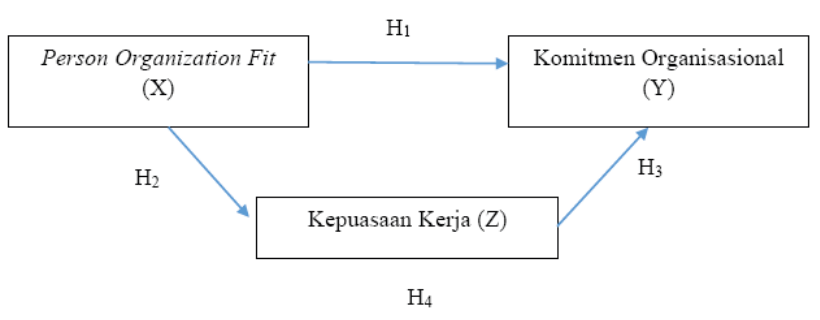

Gambar 1. Kerangka Pemikiran

\section{METODE PENELITIAN}

\section{Jenis Penelitian dan Metode Pengambilan Data}

Penelitian ini merupakan jenis penelitian kuantitatif yang berupa pengujian hipotesis dengan menggunakan metode survei. Responden dalam penelitian ini sebanyak 150 orang dilakukan penelitian pada tahun 2017 . Teknik pengambilan sampel menggunakan simple random sampling. Sampel yang digunakan sebagai responden adalah pegawai edukatif dan administratif yang bekerja di IBI Darmajaya minimal memiliki masa kerja selama 1 tahun.

\section{Definisi Operasional dan Pengukuran Variabel}

Seluruh instrumen pengukuran dalam penelitian ini menggunakan definisi operasional yang sama dengan definisi konseptual dan menggunakan kuesioner yang diadapatasi dari penelitian terdahulu. Komitmen afektif diadopsi dari Mowday et al (1979) dengan 15 pertanyaan. Pertanyaan-pertanyaan tersebut di antaranya berkaitan dengan persepsi karyawan berada di dalam organisasi. Kepuasaan kerja diadopsi dari 
Pengaruh Person-Organization Fit Terhadap Komitmen Organisasional Melalui Kepuasaan Kerja ...........

Job Descriptive Index (JDI) dengan 5 pertanyaan. Pengukuran variabel kesesuaian nilai (value congruence) diadopsi dan hasil modifikasi dari Cable dan DeRue (2002). Jumlah pertanyaan terdiri dari 3 item. Pertanyaan-pertanyaan dalam kuesioner ini menilai kesesuaian nilai secara keseluruhan.

\section{Uji Instrumen}

Untuk menguji validitas dari alat ukur, penelitian ini menggunakan metode uji koefisien korelasi produk moment pearson (pearson product moment corelation coeficient). Uji reabilitas menggunakan koefisien Cronbach's Alpha. Menurut Hair et al (2010) nilai koefisien Cronbach's Alpha $\leq 0,5$ menandakan reliabilitas yang buruk, namun masih dapat digunakan untuk analisis selanjutnya, nilai reliabilitas antara 0,5 sampai 0,7 dapat diterima dan jika melebihi nilai 0,8 reliabilitas baik.

\section{Analisis Data}

Untuk menganalisis data pada penelitian, menggunakan metode Regression Analysis. Menurut peneliti mengunakan metode Regression Analysis sudah tepat digunakan untuk menganalisis model penelitian ini. Menurut Baron dan Kenny (1986) metode regression analysis tersebut tepat digunakan untuk mengidentifikasi pengaruh variabel independen pada variabel dependen, terutama ketika terdapat variabel mediasi. Penelitian ini menggunakan pengujian mediasi untuk menjawab hipotesis 4 , dan pengujian regresi sederhana untuk menjawab hipotesis 1,2 , dan 3 .

\section{HASIL PENELITIAN DAN PEMBAHASAN}

\section{Profil Deskriptif Responden}

Secara keseluruhan total kuesioner yang didistribusikan berjumlah 150 kuesioner. Total kuesioner yang kembali sebanyak 150 kuesioner atau $100 \%$, terdiri dari 140 kuesioner yang dapat diolah dan 10 kuesioner yang tidak dapat diolah. Pengambilan data dilakukan pada bulan Agustus 2016. Secara umum, mayoritas responden adalah Pria (85 orang atau $65 \%$ ) dengan usia kisaran 30 - 50 tahun keatas. Kebanyakan responden memiliki jabatan sebagai pegawai edukatif atau dosen (87 orang atau 58\%) dengan masa kerja lebih dari 3 tahun.

\section{Hasil Uji Instrumen}

Dari hasil uji validitas dengan menggunakan uji koefisien korelasi product moment pearson, 23 butir pertanyaan dinyatakan valid. Selanjutnya untuk uji reliabilitas dengan menggunakan uji cronbach's alpha menunjukkan variabel komitmen organisasional memiliki tingkat reliabilitas paling tinggi dengan $\alpha=0,754$, diikuti dengan variabel kesesuaian nilai dengan $\alpha$ $=0,786$, dan variabel komitmen afektif dengan $\alpha$ $=0,635$.

Berdasarkan pengolahan hasil kuesioner, nilai mean pada setiap variabel sebagai berikut:

a. Nilai mean untuk variabel person organization fit, yaitu sebesar 43,84

b. Nilai mean untuk variabel kepuasaan kerja, yaitu sebesar 46,32.

c. Nilai mean untuk variabel komitmen organisasional, yaitu sebesar 12,57. 
Tabel 1. Pengujian Hipotesis

\begin{tabular}{|c|c|c|c|c|}
\hline VARIABEL & $\beta$ & $t$ & $p$ & Adjusted $\mathbf{R}^{2}$ \\
\hline \multicolumn{5}{|l|}{ Tahap 1 (X ke Y) } \\
\hline $\begin{array}{l}\text { Person organization } \\
\text { fit }(\mathrm{X}) \text { dan Komitmen } \\
\text { Organisasional }(\mathrm{Y})\end{array}$ & 0,315 & 3,065 & $0,000 * *$ & 0,116 \\
\hline \multicolumn{5}{|l|}{ Tahap 2 (X ke M) } \\
\hline $\begin{array}{l}\text { Person organization fit (X) } \\
\text { dan Kepuasaan kerja (M) }\end{array}$ & 0,425 & 3,786 & $0,000^{* *}$ & 0,237 \\
\hline \multicolumn{5}{|l|}{ Tahap 3 (M ke Y) } \\
\hline $\begin{array}{l}\text { Kepuasaan kerja }(\mathrm{M}) \text { dan } \\
\text { Komitmen organisasional } \\
(\mathrm{Y})\end{array}$ & 0,478 & 4,136 & $0,000 * *$ & 0,276 \\
\hline \multicolumn{5}{|l|}{ Tahap $4(X, M$, ke Y) } \\
\hline Sosialisasi Organisasi (X) & 0,008 & 1,075 & 0,347 & \multirow{2}{*}{0,254} \\
\hline Kesesuaian Nilai (M) & 0,527 & 4,667 & $0,000 * * *$ & \\
\hline
\end{tabular}

Sumber:Data yang diolah (2015)

Berdasarkan data diatas, P-O fit berpengaruh pada komitmen organisasional. Hal ini dapat dilihat dari nilai $\beta=0,315 ; \mathrm{t}=3,065 ; \mathrm{p}<$ 0,05 , sehingga dapat disimpulkan bahwa hipotesis pertama diterima. $\mathrm{H}_{1}$ : Person organization fit (P-O fit) berpengaruh positif dan signifikan pada komitmen organisasional.Melihat tabel 1 dapat dilihat bahwa peson organization fit berpengaruh pada kepuasaan kerja. Hal ini dapat dilihat dari nilai $\beta=0,425 ; \mathrm{t}=3,786 ; \mathrm{p}<0,05$, sehingga dapat disimpulkan hipotesis kedua diterima. $\mathrm{H}_{2}$ : Person organization fit (P-O fit) berpengaruh positif dan signifikan pada kepuasaan kerja.Dari tabel 1 dapat dilihat bahwa kepuasaan kerja berpengaruh pada komitmen organisasional. Hal ini dapat dilihat dari nilai $\beta=0,478 ; \mathrm{t}=4,136 ; \mathrm{p}<0,05$, sehingga dapat disimpulkan hipotesis ketiga diterima. $\mathrm{H}_{3}$ : Kepuasaan kerja berpengaruh positif dan signifikan pada komitmen organisasional. Tabel 1 menunjukkan bahwa kepuasaan kerja memediasi pengaruh P-O fit pada komitmen organisasional. Pengaruh langsung $\mathrm{P}-\mathrm{O}$ fit pada komitmen organisasional positif akan tetapi tidak signifikan $(\beta=0,008 ; t=1,075 ; p>0,05)$. Namun, pengaruh $\mathrm{P}-\mathrm{O}$ fit pada komitmen organisasional setelah dimasukkan variabel kepuasaan kerja adalah signifikan $(\beta=0,4527 ; \mathrm{t}=4,667 ; \mathrm{p}<0,05)$. Hasil ini menunjukkan hipotesis keempat terdukung. $\mathrm{H}_{4}$ : Kepuasaan kerja memediasi pengaruh person organization fit pada komitmen organisasional.

\section{Pembahasan}

Pada penelitian ini P-O fit terbukti berpengaruh positif dan signifikan pada komitmen organisasional. Penelitian ini sejalan dan turut mendukung hasil penelitian yang dilakukan oleh Chen et al (2016) yang menyatakan bahwa P-O fit berpengaruh positif dan signifikan pada komitmen organisasional. Hal ini dikarenakan, jika nilai-nilai individu dengan organisasi mengalami kesesuaian maka karyawan memiliki keyakinan yang kuat, sehingga individu akan mengarah pada sikap yang positif. Bao et al (2012) menyebutkan bahwa ketika berbagai pihak di dalam organisasi memiliki nilai yang sama, mereka akan memiliki tujuan yang sama, orientasi sikap yang sama, mekanisme pengolahan informasi yang sama, dan komunikasi yang baik. Pada gilirannya, kesesuaian nilai menyebabkan kemudahan dalam berkomunikasi, berkerjasama, dan menciptakan lingkungan tempat bekerja yang kondusif. Sehingga karyawan menganggap dirinya memiliki peran yang besar di dalam organisasi dan menganggap pekerjaan mereka bukan hanya sekedar pekerjaan, tetapi sebuah pengalaman atau misi yang memerlukan peran penting karyawan tersebut. Oleh karena hal ini, karyawan akan secara afektif terikat dengan organisasi.

P-O fit dalam penelitian ini juga terbukti berpengaruh positif dan signifikan pada kepuasaan kerja. Hal ini sejalan dengan penelitian Verplaken (2003) yang menemukan P-O fitberpengaruh positif dan signifikan pada kepuasaan kerja. Adnan dan Muhammad (2010) menyatakan bahwa ketika P-O fit tercipta didalam organisasi, maka berbagai pihak di dalam organisasi memiliki rasa 
Pengaruh Person-Organization Fit Terhadap Komitmen Organisasional Melalui Kepuasaan Kerja ...........

kolegalitas yang tinggi dan adanya sikap saling terbuka, sehingga meningkatkan kepuasaan kerja karyawan. Wheller et al (2007) menemukan bahwa P-O fit membuat karyawan akan lebih mudah dalam berkerjasama sehingga menujang kinerjanya, dan ada akhirnya karyawan akan memiliki tingkat kepuasaan kerja yang tinggi.

Hasil lain dari penelitian ini adalah kepuasaan kerja terbukti berpengaruh positif dan signifikan pada komitmen organsiasional. Hal ini sejalan dan turut mendukung hasil penelitian yang dilakukan oleh Patrick dan Sonia (2012) yang menyatakan kepuasaan kerja berpengaruh positif dan signifikan pada komitmen organisasional. Hal ini dikarenakan, komponen kepuasaan kerja seperti gaji, tunjangan, kesempatan mengalami kemajuan, dan juga pengawasan kerja yang baik membawa perasaan positif kepada karyawan. Sehingga, merangsang karyawan untuk memiliki keyakinan bahwa tinggal di dalam organisasi merupakan suatu hal yang tepat dilakukan.

Penelitian ini juga menemukan bahwa kepuasaan kerja memediasi pengaruh P-O fit pada komitmen organisasional. Ren dan Hamann (2013) menyatakan bahwa ketika terdapat kesesuaian nilai antara individu dan organisasi, maka individu akan memiliki rasa kebersamaan mencapai tujuan bersama. Ketika tujuan itu harus dicapai, individu akan mengeluarkan segenap pengetahuan, kemampuan, dan keahliannya. Sehingga, ketika karyawan mengeluarkan seluruh potensi dirinya demi tercapainya tujuan bersama tersebut, maka individu mendapatkan imbalan berupa prestasi kerja. Pada akhirnya, karyawan akan memiliki tingkat kepuasaan kerja yang tinggi. Powel dan Meyer (2003) menemukan bahwa ketika karyawan memiliki prestasi kerja yang baik, karyawan tersebut akan berusaha untuk tinggal di dalam organisasi. Hal ini dikarenakan, karyawan akan kehilangan prestasi kerjanya ketika harus meninggalkan organisasi. Silva (2006) menunjukkan bahwa aspek kepuasaan kerja seperti, promosi, penghargaan, dan sifat pekerjaan mempengaruhi keinginan individu untuk tinggal di dalam organisasi.

\section{KESIMPULAN DAN SARAN}

Berdasarkan hasil penelitian dan pembahasan yang telah dilakukan, dapat diambil kesimpulan,yakni pertama, P-O fit berpengaruh positif dan signifikan pada komitmen organisasional. Kedua, P-O fit berpengaruh positif dan signifikan pada kepuasaan kerja. Ketiga, kepuasaan kerja berpengaruh positif dan signifikan pada komitmen organisasional. Keempat, kepuasaan kerja memediasi pengaruh PO fit pada komitmen organisasional.

Beberapa saran untuk penelitian dimasa yang akan datang, terkait dengan penelitian ini adalah penelitian ini menggunakan sampel pada institusi pendidikan, yaitu di IBI Darmajaya, Bandarlampung. Hasil penelitian mungkin berbeda ketika menggunakan sampel lembaga lain yang memiliki nilai yang berbeda. Oleh karena itu, untuk meningkatkan generalisasi penelitian, dibutuhkan penelitian lebih lanjut dengan menggunakan sampel yang berbeda. Selanjutnya, Penelitian ini menggunakan P-O fit secara keseluruhan untuk melihat bagaimana pengaruh pada komitmen organisasional. Penelitian lebih lanjut bisa menggunakan dimensi dari P-O fit, seperti: goal congruence, need-structure fit, dan personality-climate fit. Penelitian ini menggunakan variabel dependen komitmen organisasional, Penelitian lebih lanjut bisa pengaruh P-O fit terhadap dimensi komitmen organisasional seperti, komitmen normatif, komitmen kontinuan, dan komitmen afektif. 


\section{DAFTAR PUSTAKA}

Adnan, R., Muhammad, R. (2010). “Antecedents of Job Satisfaction: A Study ofTelecom Sector". Perspectives of Innovations, Economics and Business, Vol. 4, pp. 6673.

Allen, N. J., Meyer, J. P. (1990), "The Measurement and Antecedents Of Affective, Continuance, and Normative Commitment To The Organization". Journal Of Occupational Psychology, Vol. 63, pp. 1-18.

Alluto, J. A., Hrebiniak, L. G., \& Alonso, R. C. (1973). "On operationalizing the concept of commitment". Social Forces, Vol. 51, pp. 448-454.

Autry, C. W., Daugherty, P.J., (2003). "Warehouse operation employees: linkin personorganization fit, job satisfaction and coping response". Journal of Business Logistic, Vol. 24, pp. 171-197.

Baron, M. R., Kenny, D. A. (1986), "The Moderator-Mediator Variable Distinction in Social Psychological Research: Conceptual, Strategic, and Statistical Considerations". Journal of Personality and Social Psychology, Vol. 51, pp. 1173-1182.

Bao, Y., Dolan, S., Tzafrir, S. (2012), "Value Congruence In Organization: Literature Review, Theoretical Perspectives, and Future Direction". Esade Working Paper.

Biswas. S \& J. Bhatnagar. 2013. Mediator Analysis of Employee Engagement: Role of Perceived Organizational Support, P-O Fit, Organizational Commitment, and Job Satisfaction. VIKALPA 38 (1): 27-40.
Bowen, D. E., Ledford, G. E., Nathan, B. R. (1991), "Hiring for the organization, not the job". Academy of Management Executive, Vol. 5, pp. 3551.

Box, W. R., Odom, R. Y., Dunn, M. G. (1991), “Organizational Values and Value Congruency and Their Impact on Satisfaction, Commitment, and Cohesion". Public Personnel Management, Vol. 20, pp. 195205.

Bretz, R. D. Jr., \& Judge, T. A. (1994). "Personorganization fit and the theory of work adjustment: implications for satisfaction, tenure, and career success". Journal of Vocational Behavior, Vol. 44, pp. 3254.

Cable, M. DeRue, S. D. (2002), “ The Convergent and Discriminant Validity Of Subjective Fit Perseption". Journal of Applied Psychology, Vol. 87, pp. 875-884.

Chatman, J. (1991), "Matching People and Organizations: Selection and Socialization In Public Accounting Firm". Administrative Science Quartely, Vol. 36, pp. 459-484.

Chen, P., Sparrow, P., Cooper. C. (2016). “ The relationship between personorganization fit and job satisfaction". Journal of Managerial Psychology, Vol. 31, pp. 946-959.

Ferris, G. R., Judge, T. A. (1991). "Personnel/ human resource management: A political influence perspective". Journal of Management, Vol. 17,pp. 447-488.

Gregory. B. T, M. D. Albritton \& T. Osmonbekov. 2010. The Mediating Role of Psychological Empowerment on The Relationship Between P-O Fit, Job Satisfaction, and in role Performance. Journal Business Psychological 25: 639-647. 
Pengaruh Person-Organization Fit Terhadap Komitmen Organisasional Melalui Kepuasaan Kerja

Gunlu E, Mehmet Aksarayli and Nilufer Percin (2010). "Job Satisfaction and Organizational Commitment of Hotel Managers in Turkey",. International Journal of Contemporary Hospitality Management, Vol. 22, pp. 693-717.

Hanisch, K. A., Hulin, C. L. (1990). "Retirement as a voluntary organizational withdrawal behavior". Journal of Vocational Behavior. Vol. 37, pp. 60-78.

Hair, J. F., Black, W. C., Babin, B. J., Anderson, R. E., and Tatham, R. L. (2006), "Multivariate data analysis". 6th ed. New Jersey: Prentice Hall.

Hsieh. A. T, Edb, \& Y. Y Chen. 2011. The Influence of Employee Referalls on P-O Fit. Public Personnal Management 40 (4): 327-339.

Jutras. J \& CMathieu. 2016. Person Organizational Fit Relationaship With Job Satisfaction and Turnerover: The Mediating Influence of Leader Member Exchange. Academic of Strategic Management Journal 15 (1): 71-84

Kristof, A. L. (1996), "Person-Organization Fit: An Integrative Review Of Its Conceptualization, Measurement, and Implications". Personnel Psychology, Vol. 49, pp. 1-49.

Kwantes, C. T. (2009). "Culture, Job Satisfaction and Organizational Commitment in India and the United States", Journal of Indian Business Research, Vol. 1, pp. 196-212.

Meglio, B. M., Ravlin, E. C., Adkins, C. L. (1992), "The Measurement Of Work Value Congruence: A Field Study Comparison". Journal Of Management, Vol. 18, pp. 33-43.

Meyer, J. P., Stanley, D. J., Herscovitch, L., Topolnytsky. (2002), "Affective,
Continuance, And Normative Commitment To The Organization: A Meta-Analysis Of Antecedents, Correlates, and Consequences". Journal of Vocational Behavior, Vol. 61 (1), pp. 20-52.

Mount, M. K., Muchinsky, P. M. (1978). "Personenvironment congruence and employee job satisfaction: A test of Holland's theory". Journal of Vocational Behavior, 13, 84-100.

Mowday, R., Steers, R. and Porter, L. (1979). "The measurement of organizational commitment". Journal of Vocational Behaviour, Vol. 14, pp. 224-247.

Mowday, R. T., Porter, L. W., Steers, R. M. (1982), "Employee-Organization Linkages The Psychology of Commitment, Absenteeism, and Turnover. New York: Academic Press.

Mosadeghrad. A. M., Ferlie, E, and Rosenberg, D. (2008). "A Study of the Relationship Between Job Satisfaction, Organizational Commitment and Turnover Intention Among Hospital Employees", Health Service Management Research, Vol. 21, pp. 211-227.

Netemeyer, R.G, Boles, S. B., Mckee, D. O. (1997). "An Investigation Into The Antecendents of Organizational Citizienship Behaviors in a Personal Selling Context". Journal of Marketing, Vol. 61, pp. 8598.

Ren, T., Hamann, D. J. (2015). “ Employee value congruence and job attitudes: the role of occupational status". Personnel Review, Vol. 44, pp. 550-566.

Robbins, S. (2001). Perilaku Organisasi. (Organizatonal Behaviour). Salemba Empat. Jakarta. 
Robbins, S. (2003), Organizational Behavior: International Edition, 10th Edition, Prentice Hall, New Jersey.

Sanuasi,Anwar. 2012. Organisasi dan Komitmen Locus Of Control Atas Partisipasi Penuyusunan Estimasi Tehadap Kinerja Pemerintah Kota Bandar Lampung. Jurnal Manajemen Keuangan 1 (1): 107.125.

Schneider, B. (1987). The people make the place. Personnel Psychology, 40, 437-453.

Schneider, B., Goldstein, H.W., Smith, D. B. (1995). "The ASA Framework: An Update". Personnel Psychology, Vol. 48, 747-779. Sekiguchi, Tomoki. ( 2004). “ Person Organization Fit and person Job Fit in Employee Selection: A Review of The Literature". Osaka Keidai Ronshu, Vol. 54, pp. 179-196.

Silva, P. (2006). "Effects of disposition on hospitality employee job satisfaction and commitment". International Journal of Contemporary Hospitality Management. Vol. 18, pp. 317-328.

Silverthorne, C. (2004), "The Impact Of Organizational Culture and PersonOrganization Fit On Organizational Commitment and Job Satisfaction In Taiwan". The Leadership and Organization Development Journal, Vol. 25, pp. 592-599.

Smith P C, Kendall L M and Hulin C L (1969). "The Measurement of Satisfaction in Work and Retirement", Rand McNelly, Chicago.
Turban, D. B., \& Keon, T. L. 1994. “ Organizational attractiveness: an interactionist perspective". Journal of Applied Psychology, Vol. 78, pp. 184193.

Valentine, S., Godkin, L., Lucero, M. (2002), "Ethnical Context, Organizational Commitment, and Person-Organization Fit". Journal Of Business Ethics, Vol. 41, pp. 349-360.

Vancouver, J. B., Schimt, N. W. (1991), “An Explanatory Examination Of PersonOrganization Fit and Organizational Goal Congruence". Personnel Psychology, Vol. 44, pp. 333-352.

Verplaken., Holland, W. (2002), "Motivated Decision Making: Effect Of Acctivism and Self-Centrality on Value in Choice and Behavior". Journal of Personality and Social Psyhology. Vol. 82, pp. 434447.

Verquer, L. M., Nehhr, T., Wagner, S. (2002). “A Meta-Analysis Of Relations Between Person-Organization Fit and Work Attitudes". Journal of Vocational Behavior, Vol. 63, pp. 473-489

Wheeler, R. A., Gallager, C. V., Brouer, B. L., Sablynski. C. (2007). " When personorganization(mis)fit and(dis)satisfaction lead to turnover The moderating role of perceived job mobility". Journal of Managerial Psychology, Vol. 22, pp. 203-219. 